\title{
Effects of body conformation and udder morphology on milk yield of zebu cows in North region of Cameroon
}

\author{
Kilekoung Jean-Pierre Mingoas ${ }^{1}$, Julius Awah-Ndukum², Houinga Dakyang³ and Pagnah André Zoli ${ }^{3}$
}

1. Department of Physiology and Biochemistry, School of Veterinary Medicine and Sciences, University of Ngaoundere, PO Box 454 Ngaoundere, Cameroon; 2. Department of Anatomy, Histology and Embryology, School of Veterinary Medicine and Sciences, University of Ngaoundere, PO Box 454 Ngaoundere, Cameroon; 3. Department of Biotechnology of Reproduction, School of Veterinary Medicine and Sciences, University of Ngaoundere, PO Box 454 Ngaoundere, Cameroon. Corresponding author: Kilekoung Jean-Pierre Mingoas, e-mail: jmingoas@yahoo.fr

Co-authors: JA: awahndukum@yahoo.co.uk, HD: houinga2013@gmail.com, PAZ: andre.zoli@yahoo.fr Received: 07-03-2017, Accepted: 06-07-2017, Published online: 11-08-2017

doi: 10.14202/vetworld.2017.901-905 How to cite this article: Mingoas KJ, Awah-Ndukum J, Dakyang H, Zoli PA (2017) Effects of body conformation and udder morphology on milk yield of zebu cows in North region of Cameroon, Veterinary World, 10(8): 901-905.

\begin{abstract}
Aim: The aim of the study was to assess the effect of udder morphological characteristics on milk yield in zebu cows of Cameroon.

Materials and Methods: The diameter and height of the udder, length and diameter of the teat, and the milk yield were measured in 29 Djafun (Red Mbororo) and 19 Aku (White Fulani) cows in Louggueré zootechnical station in the North region of Cameroon.

Results: Overall, strong positive correlation $\left(\mathrm{r}_{\mathrm{p}}=0.60\right)$ between the diameter $(240.21 \pm 28.58 \mathrm{~mm})$ and height $(131.12 \pm 23.64 \mathrm{~mm})$ of udders $(\mathrm{p}<0.001)$ and between length $(39.51 \pm 6.44 \mathrm{~mm})$ and diameter $(19.85 \pm 3.08 \mathrm{~mm})$ of teats $\left(r_{p}=0.78\right)$ were found in the zebu cows. Udder morphologic characteristics varied significantly $(p<0.005)$ according to breed, lactation stage and parity, and height at whiters. There was significant $(\mathrm{p}<0.001)$ correlations between udder diameter $\left(r_{p}=0.541\right)$ and height $\left(r_{p}=0.549\right)$ with milk yield.

Conclusion: This study ascertained udder morphological characteristics values in local zebu cows, and showed that udder size is strong and positively correlated to milk yield. The findings are useful in genetic improvement programs of zebu cows.
\end{abstract}

Keywords: Cameroon, lactation stage, milk yield, teat diameter, parity, zebu cow.

\section{Introduction}

Milk is important as foodstuff for human consumption and in world food security programs. In Cameroon, milk production was estimated at 56,850 tons in 2012 when 216,000 tons was needed in the country [1]. There is annual individual milk consumption in Cameroon is $14.5 \mathrm{~kg}$, which is less than the recommended amount of $22 \mathrm{~kg}$ [2]. Thus, there is gross shortage between milk production and consumption. This situation persists and lower milk production performances of local breeds $0.5-3 \mathrm{~L}$ of milk per day are among the contributing factors [1]. Interesting findings have been reported in different species in various areas worldwide to improve milk production. Reports have showed positive correlations between udder characteristics and milk production in Tunisia [3] and India [4,5]. While Ayadi et al. [6] reported that daily milk production is positively correlated to distance between teats $(r=0.61$,

Copyright: Mingoas, et al. Open Access. This article is distributed under the terms of the Creative Commons Attribution 4.0 International License (http://creativecommons.org/licenses/ by/4.0/), which permits unrestricted use, distribution, and reproduction in any medium, provided you give appropriate credit to the original author(s) and the source, provide a link to the Creative Commons license, and indicate if changes were made. The Creative Commons Public Domain Dedication waiver (http:// creativecommons.org/publicdomain/zero/1.0/) applies to the data made available in this article, unless otherwise stated. $\mathrm{p}<0.05)$ and udder depth $(\mathrm{r}=0.29, \mathrm{p}<0.05)$ in Najdi sheep of Tunisia. In Chile, Daniela [7] recorded positive correlations of $0.77(p<0.0001)$ between udder depth and milk production and $0.60 \quad(\mathrm{p}<0.0001)$ between udder height and milk production in local cows. Furthermore, Khan and Khan [8] found genetic and phenotypic correlations between udder biometrics and milk yield in Pakistan Sahiwal cows.

The relationships between udder characteristics and milk yield can be useful tools in selecting animals in dairy production systems. Although there are many livestock species and breeds with good potentials for dairy production in Cameroon, there is a dearth of information on the characteristics of their accessory reproductive organs and how the measurements of these organs relate to reproductive and dairy performances of livestock in the country.

The aim of this study, therefore, was to assess the effect of udder morphological traits on milk yield in local zebu cows in the northern region of Cameroon.

\section{Materials and Methods \\ Ethical approval}

Animals were handled and experiments conducted in accordance with laws and regulations of the country and ethical rules (MINEPIA Delegations in North Region; School of Veterinary Medicine and Sciences of the University of Ngaoundere). 


\section{Study location and management of animals}

The study was conducted from August to November 2015 in the Louggueré zootechnical station in the northern region of Cameroon $\left(13^{\circ} 30^{\prime}-13^{\circ} 90^{\prime} \mathrm{LE}\right.$ and $\left.9^{\circ} 20^{\prime}-10^{\circ} 15^{\prime} \mathrm{LN}\right)$.

The animals used in this study were housed on station and had been treated before measurements against intestinal helminthosis and blood parasites with albendazole (Kelaphen ${ }^{\circledR}$, KELA, Belgium) at $7.5 \mathrm{mg} / \mathrm{kg}$ orally and diminazene aceturate (Trypadim ${ }^{\circledR}$, MERIAL, France) at $3.5 \mathrm{mg} / \mathrm{kg}$ by intramuscular injection following manufacturers' prescriptions. The animals had also been vaccinated against the prevailing diseases in the region (namely, pasteurellosis, contagious bovine pleuropneumonia, and black quarter) and treated with the acaricide deltamethrin to control ectoparasites. They were grazed on pasture plots on station and given salt every 3 days. Water was available ad libitum.

\section{Udder measurements}

The morphological measurements were evaluated on 29 Djafun (Red Mbororo) and 19 Aku (White Fulani) cows with parity and lactation stage varying between 1 and 3 (Table-1), before milking as shown in Table-2 $[3,6,7]$.

Height at the whiters and thoracic circumference were also measured as previously described by Toszer and Bedo [9].

Table-1: Distribution of study cows according to breed and lactation rank and stage.

\begin{tabular}{|c|c|c|c|c|c|c|}
\hline \multirow{2}{*}{$\begin{array}{l}\text { Breed } \\
\text { Parity }\end{array}$} & \multicolumn{3}{|c|}{$\begin{array}{c}\text { Mbororo } \\
\text { Djafun (Red } \\
\text { Mbororo) } \\
\text { (No. of } \\
\text { cows=29) }\end{array}$} & \multicolumn{3}{|c|}{$\begin{array}{c}\text { Mbororo } \\
\text { Aku (White } \\
\text { Fulani) } \\
\text { (No. of } \\
\text { cows=19) }\end{array}$} \\
\hline & 1 & 2 & 3 & 1 & 2 & 3 \\
\hline No. of cows & 17 & 10 & 2 & 5 & 6 & 8 \\
\hline Lactation stage & 1 & 2 & 3 & 1 & 2 & 3 \\
\hline No. of cows & 9 & 6 & 14 & 7 & 6 & 6 \\
\hline
\end{tabular}

Lactation rank (parity): $1=1^{\text {st }}$ lactation, $2=2^{\text {nd }}$ lactation, $3=3^{\text {rd }}$ lactation. Lactation stage: $1=$ Earlier lactation period, $2=$ Mid-lactation, $3=$ Late lactation

Table-2: Description of udder morphological measurements.

\begin{tabular}{ll}
\hline $\begin{array}{l}\text { Udder morphological } \\
\text { traits (mm) }\end{array}$ & Description \\
\hline Udder depth (Ud) & $\begin{array}{l}\text { Distance between udder rear } \\
\text { and front attachments } \\
\text { Distance between cistern } \\
\text { abdominal attachment and teat } \\
\text { emergence plan } \\
\text { Udder height (Uh) }\end{array}$ \\
Udder length (UI) & $\begin{array}{l}\text { attachment of udder to the } \\
\text { point where fore udder blends } \\
\text { smoothly with the body passing } \\
\text { the cloth tape in between right } \\
\text { and left teats } \\
\text { Measured between rear and } \\
\text { front base of teat at emergence } \\
\text { of udder }\end{array}$ \\
\hline
\end{tabular}

Milk yield measurement was performed manually once every 2 days, from August to November 2015. After stimulating sucking by calf and proper cow restraint, the overall milk quantity was collected and measured in a graduated container.

\section{Statistical analysis}

Statistical analyses were performed with Fisher least significant differences at $\mathrm{p}<0.05$, using STATGRAPHICS centurion $1 / .1 .08^{\circledR}$ software, with the following model:

$\mathrm{Y}_{\mathrm{ijklmn}}=\mu+\mathrm{T}_{\mathrm{i}}+\mathrm{R}_{\mathrm{j}}+\mathrm{S}_{\mathrm{k}}+\mathrm{P}_{1}+\mathrm{H}_{\mathrm{m}}+\mathrm{e}^{\mathrm{ijklmn}}$, where

$\mathrm{Y}_{\mathrm{ijk}}^{\mathrm{ijk} / \mathrm{k} n}=$ Studied dependent variable (udder depth, udder height, udder length, teat diameter, and milk production); $\mu=$ Mean; $\mathrm{T}_{\mathrm{i}}=$ Genetic effect $(\mathrm{i}=1-2)$; $\mathrm{R}_{\mathrm{j}}$ : Effect of lactation rank $(\mathrm{j}=1-3) ; \mathrm{S}_{\mathrm{k}}=$ Effect of lactation stage $(\mathrm{k}=1-3) ; \mathrm{P}=$ Effect of thoracic circumference $(1=1-19) ; H_{m}$ : Effect of height at whiters $(m=1$ 20 ); and $\mathrm{e}^{\mathrm{ijk} k \mathrm{mn}}=\mathrm{Associated}$ random error. Factors such as season of the year and husbandry practices were not considered during analysis.

\section{Results}

\section{Udder morphological characteristics in zebu cows}

The udder morphological traits in lactating zebu cows are presented in Table-3. Overall, the udder mean depth was above $240 \mathrm{~mm}$ (maximum of $309 \mathrm{~mm}$ and minimum of $143 \mathrm{~mm}$ ), while mean udder height, length, and teat diameter were more than 131, 39, and $19 \mathrm{~mm}$, respectively. Low values of coefficients of variation were recorded.

The udder height was the only morphological characteristic significantly influenced $(\mathrm{p}<0.001)$ by udder portion (Table-4). Furthermore, the fore teat mean lengths and diameters were significantly higher $(p<0.05)$ compared to hind teats.

Except for the hind right teat length which did not show any difference according to breed $(p>0.05)$, the udder heights and diameters and teat lengths and diameters, irrespective of the udder portion (left or right), were consistently higher $(\mathrm{p}<0.05)$ in the White Fulani than in the Red Mbororo (Table-4).

\section{Effect of parity and lactation stage on udder morpho- logical traits}

The results showed that the udder depth significantly increased $(\mathrm{p}<0.05)$ at the $3^{\text {rd }}$ parity (Figure- 1$)$ and decreased $(\mathrm{p}<0.05)$ at the $3^{\text {rd }}$ stage of lactation (Figure-2) while the udder height increased $(\mathrm{p}<0.05)$ at the $2^{\text {nd }}$ parity (Figure-1) and decreased at the $3^{\text {rd }}$ stage of lactation (Figure-2).

There was no significant variation $(p>0.05)$ of teat size according to parity and stage of lactation.

\section{Relation between body conformation, udder mor- phological characteristics and milk yield}

Udder depth, udder height, height at whiters, and thoracic circumference had highly significant $(p<0.001)$ effects on milk yield, while teats characteristics had no effect ( $\mathrm{p}>0.05)$ (Table-5).

A positive and highly significant $(p<0.001)$ correlation $\left(r_{p}=0.60\right)$ was found between udder 
Table-3: Udder characteristics in zebu lactating cows.

\begin{tabular}{lcccc}
\hline Characteristics & \multicolumn{3}{c}{ Dimensions $\mathbf{( m m )}$} \\
\cline { 2 - 5 } & $\boldsymbol{\mu \pm S D}$ & Minimum & Maximum & CV (\%) \\
\hline Udder depth & $240.21 \pm 28.58$ & 143.00 & 309.00 & 11.89 \\
Udder height & $131.12 \pm 23.64$ & 77.50 & 197.50 & 18.02 \\
Teat length & $39.51 \pm 6.44$ & 22.75 & 63.50 & 16.30 \\
Teat diameter & $19.85 \pm 3.08$ & 12.75 & 29.00 & 15.51 \\
\hline
\end{tabular}

$\mu=$ Mean, $\mathrm{SD}=$ Standard deviation, $\mathrm{CV}=$ Coefficient of variation

Table-4: Variations of morphological characteristics ( $\mu \pm S D$ ) according to udder portion and cow's breed.

\begin{tabular}{lcccccc}
\hline Variables & \multicolumn{4}{c}{ Udder portion } \\
\cline { 2 - 7 } & \multicolumn{5}{c}{ Left } & \multicolumn{2}{c}{ Right } \\
\hline Breed & Zebu cows & White Fulani & Red Mbororo & Zebu cows & White Fulani & Red Mbororo \\
No. of cows & 48 & 19 & 29 & 48 & 19 & 29 \\
Udder height $(\mathrm{mm})$ & $127.24 \pm 25.35^{\mathrm{A}}$ & $135.92 \pm 26.89^{\mathrm{a}}$ & $114.45 \pm 15.95^{\mathrm{b}}$ & $135.03 \pm 22.74^{\mathrm{B}}$ & $142.32 \pm 23.93^{\mathrm{c}}$ & $124.37 \pm 15.72^{\mathrm{d}}$ \\
Fore teat length $(\mathrm{mm})$ & $41.29 \pm 8.04^{\mathrm{A}}$ & $42.75 \pm 8.52^{\mathrm{a}}$ & $39.16 \pm 6.77^{\mathrm{b}}$ & $40.00 \pm 8.77^{\mathrm{A}}$ & $40.89 \pm 10.00^{\mathrm{c}}$ & $38.69 \pm 6.41^{\mathrm{d}}$ \\
Hind teat length $(\mathrm{mm})$ & $38.28 \pm 8.08^{\mathrm{A}}$ & $39.65 \pm 8.50^{\mathrm{a}}$ & $36.28 \pm 6.97^{\mathrm{b}}$ & $28.48 \pm 7.56^{\mathrm{A}}$ & $39.69 \pm 7.87^{\mathrm{c}}$ & $38.71 \pm 6.55^{\mathrm{d}}$ \\
Fore teat diameter $(\mathrm{mm})$ & $20.44 \pm 3.82^{\mathrm{A}}$ & $21.32 \pm 4.02^{\mathrm{a}}$ & $19.16 \pm 3.08^{\mathrm{b}}$ & $20.80 \pm 4.23^{\mathrm{A}}$ & $21.87 \pm 4.57^{\mathrm{c}}$ & $19.25 \pm 3.08^{\mathrm{d}}$ \\
Hind teat diameter $(\mathrm{mm})$ & $19.04 \pm 4.05^{\mathrm{A}}$ & $19.69 \pm 4.21^{\mathrm{a}}$ & $17.07 \pm 3.41^{\mathrm{b}}$ & $19.11 \pm 3.61^{\mathrm{A}}$ & $20.13 \pm 3.70^{\mathrm{c}}$ & $17.61 \pm 2.77^{\mathrm{d}}$ \\
\hline
\end{tabular}

$\mu=$ Mean, $S D=$ Standard deviation; ${ }^{A}, B$ Values with the same superscript in a row are not significantly different $(p<0.05)$; $a, b, c, d$ Values with the same superscript in a row are not significantly different $(p<0.05)$

Table-5: Variation of milk yield in zebu cows according to morphological characteristics of udder, parity, and lactation stage.

\begin{tabular}{lccc}
\hline Variables & \multicolumn{3}{c}{ Production/milking (I) } \\
\cline { 2 - 4 } & $\mathbf{d f}$ & $\mathbf{C M}$ & $\mathbf{p}$ \\
\hline Breed & 1 & $2.83594 * * *$ & 0.0001 \\
Udder depth & 96 & $0.263927 * * *$ & 0.0000 \\
Udder height & 133 & $0.224538 * * *$ & 0.0007 \\
Teat length & 86 & $0.196823 \mathrm{~ns}$ & 0.1853 \\
Teat diameter & 53 & $0.153108 \mathrm{~ns}$ & 0.7783 \\
Parity & 2 & $0.685497^{*}$ & 0.0203 \\
Lactation stage & 2 & $3.10557 * *$ & 0.0000 \\
Height at whiters & 19 & $1.086 * * *$ & 0.0000 \\
Thoracic circumference & 18 & $1.10232 * * *$ & 0.0000
\end{tabular}

$\mathrm{df}=$ Degree of freedom, $C M=$ Mean square, $p=p$ value, $n s=$ Non significant $(p>0.05)$. *Significant $(p<0.05)$, $* *$ significant $(p<0.01), * * *$ highly significant $(p<0.001)$

depth and height (Table-6). The udder size (depth and height) was also strong and positively $(\mathrm{p}<0.001)$ correlated $\left(r_{p}=0.541\right.$ and $r_{p}=0.549$, respectively) to milk yield, especially in White Fulani than in Red Mbororo cows (Table-6). Teat length and diameter were positively and highly $(\mathrm{p}<0.001)$ correlated $\left(r_{p}=0.78\right)$ but were not significantly correlated to milk yield (Table-6).

Body conformation characteristics such as height at the whiters $\left(\mathrm{r}_{\mathrm{p}}=0.13\right)$ and thoracic circumference $\left(r_{p}=0.12\right)$ were moderately correlated to milk yield, especially in White Fulani compared to Red Mbororo cows.

\section{Discussion}

The study showed that overall udder mean depth in zebu cows was $240.21 \mathrm{~mm}$. Udder height, length, and teat diameter means were $131.12 \mathrm{~mm}$, $39.51 \mathrm{~mm}$, and $19.85 \mathrm{~mm}$, respectively. Fore teat means lengths and diameters were significantly

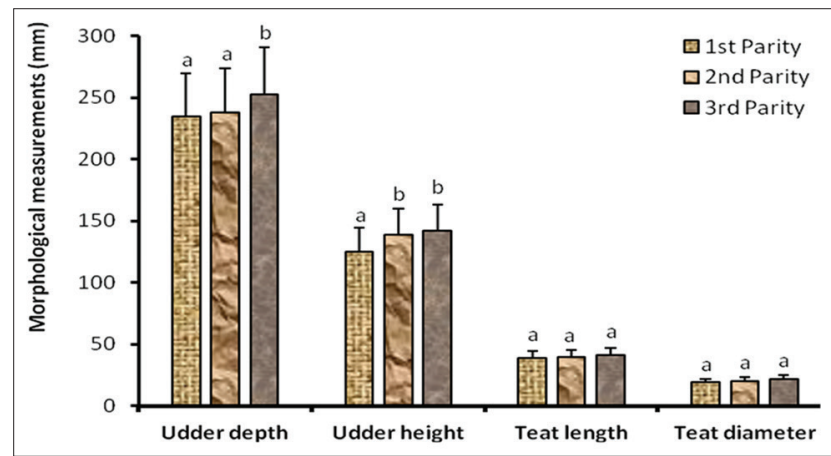

Figure-1: Udder morphological characteristics according to parity in zebu cows.

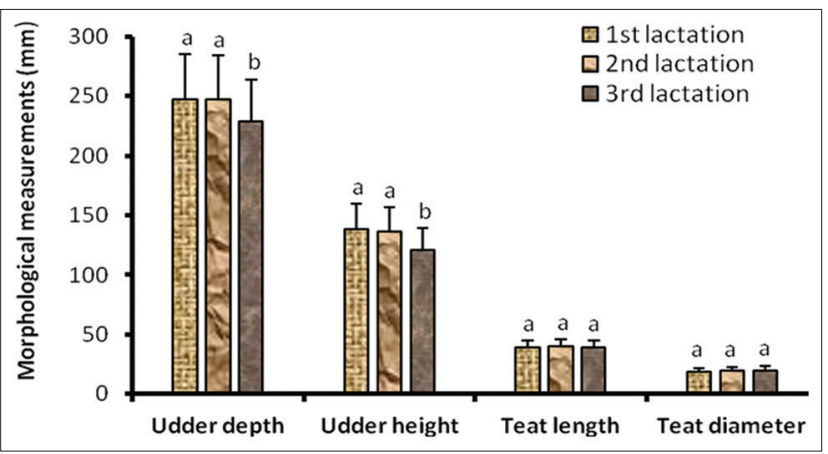

Figure-2: Udder morphological characteristics according to lactation stage in zebu cows.

higher $(\mathrm{p}<0.05)$ compared to hind teats. Udder characteristics varied with breed, udder portion, lactation stage, and parity. Udder size (depth and height) was strong and positively $(\mathrm{p}<0.001)$ correlated $\left(\mathrm{r}_{\mathrm{p}}=0.541\right.$ and $r=0.549$, respectively) to milk yield, especially in White Fulani. Low positive but significant correlations were recorded in this study between milk production and height at the whiters $\left(r_{p}=0.13\right)$ and thoracic circumference $\left(r_{p}=0.12\right)$. 
Table-6: Phenotypic correlations $\left(r_{p}\right)$ between udder morphological characteristics, body conformation and milk yield in zebu cows.

\begin{tabular}{|c|c|c|c|c|c|c|}
\hline Body conformation & Ud & Uh & TI & Td & Tc & $\mathrm{Hw}$ \\
\hline Ud & - & $0.60 * * *$ & $0.07 \mathrm{~ns}$ & $0.12 \mathrm{~ns}$ & $-0.17 \mathrm{~ns}$ & 0.03 ns \\
\hline Uh & $0.60 * * *$ & - & $0.06 \mathrm{~ns}$ & 0.13 ns & $0.03 \mathrm{~ns}$ & $0.13^{*}$ \\
\hline $\mathrm{TI}$ & 0.07 ns & $0.06 \mathrm{~ns}$ & - & $0.78 * * *$ & $0.31 * * *$ & 0.09 ns \\
\hline $\mathrm{Td}$ & $0.12 *$ & $0.13^{*}$ & $0.78 * * *$ & - & $0.24 * * *$ & $0.12 *$ \\
\hline Tc & $-0.17 \mathrm{~ns}$ & $0.03 \mathrm{~ns}$ & $0.31 * * *$ & $0.24 * * *$ & - & $0.31 * * *$ \\
\hline $\mathrm{Hw}$ & 0.03 ns & $0.13 *$ & $0.09 \mathrm{~ns}$ & $0.12 *$ & $0.31 * * *$ & - \\
\hline \multicolumn{7}{|l|}{ Milk yield } \\
\hline Overall zebu cows & $0.541 * * *$ & $0.549 * * *$ & $-0.04 \mathrm{~ns}$ & $0.006 \mathrm{~ns}$ & $0.12 *$ & $0.13 *$ \\
\hline White Fulani & $0.56 * * *$ & $0.57 * * *$ & $-0.21 *$ & $-0.19 *$ & $0.26 * *$ & $0.12 *$ \\
\hline Red Mbororo & $0.46 * * *$ & $0.49 * * *$ & $0.17 \mathrm{~ns}$ & $0.17 \mathrm{~ns}$ & $0.23 *$ & $0.10 *$ \\
\hline
\end{tabular}

ns $=$ Non significant $(p>0.05)$. *Significant $(p<0.05)$, **Significant $(p<0.01)$, ***Highly significant $(p<0.001)$. Ud=Udder depth, Uh=Udder height, Tl: Teat length, Td=Teat diameter, $\mathrm{Tc}=$ Thoracic circumference, $\mathrm{Hw}=$ Height at whiters

The udder depth recorded for Mbororo zebu cows in this study is about 1.5 times lower than the $386.8 \mathrm{~mm}$ reported for exotic Jersey cows [10]. This may be due to genetic improvement that enhanced udder growth of Jersey cows. The mean teat length and diameter were also lower than the 98.5 and $39.5 \mathrm{~mm}$ observed in Brazil Gir cows [11], the 57.7 and $22.73 \mathrm{~mm}$ in Simmentale, 53.87 and 21.20 in Holstein in Croatia [12].

Fore teats were more developed than hind teats in the zebus cows contrary to the findings of Daniela [7] and Tina et al. [12] who reported no significant difference in Holstein and Chile local cows, respectively. These differences are due to morphological traits inherent to Mbororo zebu cows and genetic improvement of Holstein and the local cows in Chile.

Udder measurements such as depth and height, teat length and diameter were significantly higher in White Fulani cows than in Red Mbororo cows. These observations confirm earlier reports of the milk production fitness of White Fulani zebu cows [13].

Udder height and depth increased in second and third parities, respectively. This result agrees with findings reported for Holstein cows that udder height and depth increase with parity [14]. This can be explained by progressive udder hypertrophy with respect to cow's age and parity [15]. However, this finding is contrary to another report that teats morphology did not varied with parity in Egyptian Buffalo cows [16]. This could be due to genetic characteristics.

Zwertvaegher et al. [14] reported that in Holstein cows, udder depth and height significantly decreased at third lactation stage, while there were no significant variations of teats morphology with respect to lactation stage. This was associated to involution phenomenon that occurs in udder according to lactation stage [15].

Udder depth and height effects were significantly proportional to milk production, while teat size had no effect on milk yield. Similar findings were reported for local cows in Chile [7], Holstein cows [14] and Simmentale cows [12] who reported that teat size was not correlated to milk production. However, a study on Tinerfen breed goats in Spain [17] stated that udder characteristics related to its globulousness such as volume, perimeter of insertion, and distance between teats are more reliable for milk yield evaluation.

Thoracic circumference and height at the whiters had a significant effect on milk yield in this study. Hans et al. [18] found similar results in Holstein cows. Low positive but significant correlations were recorded in this study between height at the whiters, thoracic circumference and milk production, suggesting that relationships exist between body conformation and milk yield in zebu cows. Similar relationships between body conformation and udder morphological development have been reported earlier [19].

In this study, positive and highly significant correlations were observed between udder depth and height and milk yield as earlier reported in Chile local cows [7] and Holstein cows [14]. These correlations were higher in White Fulani compared to the Red Mbororo cows, suggesting that White Fulani cows have a better ability for milk production.

This study, therefore, contributes to better understanding of the udder morphology of Mbororo zebu cows and suggests that large udder depth and height are useful for milk production selection criteria in genetic improvement programs.

\section{Conclusion}

This study ascertained udder morphological characteristics values in local zebu cows and showed that udder size is strong and positively correlated to milk yield. These findings are useful in genetic improvement programs of zebu cows. Further research works should focus on effects of season of the year on udder morphological characteristics and mathematical model building of udder morphology and milk yield correlations in Mbororo zebu cows.

\section{Authors' Contributions}

HD, KJM, JA, and PAZ conceived, designed and acquired private funding for the study. HD, KJM, and JA coordinated the study design and field work. DH carried out measurements and obtained field data. $\mathrm{KJM}, \mathrm{HD}, \mathrm{JA}$, and PAZ did the analysis of the information and wrote the manuscript. All authors were 
involved in revising the manuscript and approved the final manuscript.

\section{Acknowledgments}

The authors are grateful to the Staff of the Louggueré zootechnical station for their generous cooperation. This study was sponsored by authors.

\section{Competing Interests}

The authors declare that they have no competing interests.

\section{References}

1. MINEPIA. (2012) Rapport d'Activités de l'Exercice 2012, Division des Etudes, de la Planification, de la Coopération et des Statistiques. p135.

2. FAO. (2013) Rapports Panoramas I et II sur les Statistiques Agricoles et Alimentaires au Cameroun et Dans le Monde. p105.

3. Moufida A. (2014) Caractéristiques AnatomoPhysiologiques de la Glande Mammaire Chez la Chamelle en Tunisie et son Aptitude à la Mécanisation de la Traite. Thèse de Docteur en Sciences Agronomiques/Sciences de la Vie, Institut National Agronomique de Tunisie, Spécialité Sciences de Production Animale/Biologie et Agronomie. p190.

4. Patel, Y.G., Trivedi, M.M., Rajpura, R.M., Savaliya, F.P. and Monika, P. (2016) Udder and teat measurements and their relation with milk production in crossbred cows. Int. J. Environ. Sci. Technol., 5(5): 3048-3054.

5. Upadhyay, D., Patel, B.H.M., Kerketta, S., Kaswan, S., Sahu, S., Bharat, B. and Dutt, T. (2014) Study on udder morphology and its relationship with production parameters in local goats of Rohilkhand region of India. Indian J. Anim. Res., 48(6): 615-619.

6. Ayadi, M., Abdelkarim., M.M., Riyadh, S.A., Mohammed, A.A. and Mohammed, A.A. (2014) Evolution of udder morphology, alveolar and cisternal milk compartment during lactation and their relationship with milk yield in Najdi sheep. Span. J. Agric. Res., 12(4): 1061-1070.

7. Ángeles, S.O.D. (2014) Evaluation of Teat Morphology in Dairy Cows in the Main Chilean Production Systems. DVM Thesis, University of Chile, Faculty of Veterinary Sciences, Department of Development of Animal Production. p171.

8. Khan, M.A. and Khan, M.S. (2016) Genetic parameters of udder traits and their relationship with milk yield in Sahiwal cows of Pakistan. J. Anim. Plant Sci., 26(4): 880-886.

9. Toszer, J. and Bedo, S. (2000), Using of video picture analysis for measurements of cattle. Renc. Rech. Rumin., 7: 139.

10. Martina, O., Gulyás, L., Németh, S. and Gergácz, Z. (2009) Morphometric evaluation of udders in Jersey cows. Anim. Sci. Biotechnol., 42(2): 327-332.

11. Marco, A.F.P., Weber, V.B.S., Carolina, B.M.R., Cristina, S.C., Luciéna, M. and Marcos, V.S. (2010) Milk flow, teat morphology and subclinical mastitis prevalence in Gir cows. Pesqui. Agropecu. Bras., 45(12): 1507-1512.

12. Tina, B., Pero, M., Goran, V., Maja, G., Mirjana, B. and Vesna, G. (2014) Morphological and Milk Ability Breed Differences of Dairy Cows. Josip Juraj Strossmayer, University of Osijek, Faculty of Agriculture, Kralja Petra Svačića 1D, 31000 Osijek, Croatia.

13. Kamga P., Mbanya J.N., Awah N.R., Mbohou Y., Manjeli Y., Nguemdjom A., Kamga Pamela B., Njwe R.M., Bayemi P.H., Ndi C1., Imélé H., Kameni A. (2001) Effect of the Calving Season and Zootechnical Parameters on Milk Yield in the Western Highlands of Cameroon Rev. Elev Med. Vet. Pays Trop., 54(1): 55-61.

14. Zwertvaegher, I., Van Weyenberg, S., Piepers, S., Baert, J. and De Vliegher, S. (2012) Variance components of teat dimensions in dairy cows and associated factors. J. Dairy Sci., 95: 4978-4988.

15. Abdou, H., Marichatou, H., Beckers, J.F., Dufrasne, I. and Hornick, J.L. (2012) Physiology of reproduction and chemical composition of colostrum of domestic mammals. Ann. Méd. Vét., 156: 87-98.

16. Marai, I.F.M., Farghaly, H.M., Nasr, A.A., AbouFandoud, E.I. and Mohamed, I.A.S. (2001) Buffalo cow productive, reproductive and udder traits and stay ability under sub-tropical environmental conditions of Egypt. J. Agric. Trop. Subtrop., 102: 1-14.

17. Capote, J., Argüello, A., Castro, N., López, J.L. and Caja, G. (2006) Correlations between udder morphology, milk yield and milking ability with different milking frequencies in dairy goats. J. Dairy Sci., 89: 2076-2079.

18. Hans, B., Gijs, D.H. and Koeslarg, J. (2008) L'Elevage des Vaches Laitières, Série Agrodok No. 14. p7.

19. Djoko, T.D., Mbah, D.A., Mban, J.N., Kamga, P., Awah, N.R. and Bopelet, M. (2003) Crossbreeding cattle for milk production in the tropics: Effects of genetic and environmental factors on the performance of improved genotypes on the Cameroon Western High Plateau. Rev. Elev. Med. Vet. Pays Trop., 56(1-2): 63-72. 